\title{
Triassic Low Temperature Hydrothermal Activities(LTHA) From the Ordos Basin of Northern China
}

\author{
Jiyuan You ( $\sim 2373375337 @ q q . c o m)$ \\ Yulin University \\ Yiqun Liu \\ Northwest University \\ Dingwu Zhou \\ Northwest University \\ Yiyao Yang \\ Northwest University
}

\section{Research Article}

Keywords: Formation mechanism, Structural features, LTHA, Geological significance, Triassic, Ordos Basin

Posted Date: February 23rd, 2021

DOI: https://doi.org/10.21203/rs.3.rs-227659/v1

License: (c) (i) This work is licensed under a Creative Commons Attribution 4.0 International License. Read Full License 


\section{Abstract}

Because few well-preserved hydrothermal channels have been found in terrestrial sedimentary rocks, research on LTHA in geological history is relatively sparse. In this study, we present our original discovery of "hydrothermal channels" from the Chang 7 source rocks of the Triassic Yanchang Formation in the Ordos Basin, China, and provide the best evidence for deciphering LTHA preserved in the geological record (i.e., sedimentary rocks). Three possible LTHA samples (i.e., samples 1551.6, 1551.6-2 and 1574.4) were collected for this study; they were interbedded with mudstones and oil shales, indicative of a deep-lake sedimentary environment. All three samples consist mainly of anhydrite, pyrite, and dolomite with the formation of mineral zoning across the walls of these structures, suggesting a sulfate-dominated stage and a carbonate-sulfide replacement stage. Moreover, their in situ geochemistry is characterized by high $\mathrm{Eu}, \mathrm{U}, \mathrm{Th}, \mathrm{Sr}, \mathrm{Mn}$ and $\mathrm{U} / \mathrm{Th}$ ratios, which are typical indicators of hydrothermal vents. In addition, their S isotopes range from $7.89 \%$ to $10.88 \%$, the magmatic sulfur accounted for approximately $94.3 \%$, implying a possible magmatic trigger for these hydrothermal channels. All this evidence shows that the Triassic sedimentary rocks of the Ordos Basin probably contain LTHA. Comparing ancient LTHA to modern hydrothermal chimneys, we should note the important implications of LTHA; their formation mechanism may have been related to oil production, and they are possible indicators for future oil investigations. Further, they have great significance for studying the hydrothermal properties of primary dolomite.

\section{Introduction}

A submarine hydrothermal chimney is a tubular structure formed by the eruption of hydrothermal fluid on the seabed. Its structure and chemical composition are closely related to the properties of the hydrothermal fluid from which the chimney body formed. In the wall of a chimney with a thickness of 1 to $3 \mathrm{~cm}$, there are very large geochemical, thermal and mineral combination gradients. A chimney contains rich information about the properties of hydrothermal fluids and mineralization temperatures and records the growth process and growth history of the chimney body ${ }^{[1,2]}$. Based on the research results of different hydrothermal chimneys, scientists have classified them into 3 categories according to temperature and mineral composition: "black chimney", "white chimney" and "silicon chimney" $[3,4,5]$. Over the years, research on the cause and growth mechanism of hydrothermal chimneys has received attention from the international academic community. Reconstructing the formation environment and growth mechanism of the chimney body according to the different structural compositions of the chimney body is one of the important aspects. The development of related research also involves many topics, such as deep sea material circulation, energy transfer, the genesis of mineral deposits and even the origin of life ${ }^{[6,7]}$. However. The amount of research on LTHA in modern lakes is relatively low, and there is even less research on lacustrine LTHA in geological history. The reason is that although they are important specimens for studying hydrothermal mineralization and activity and extreme environments throughout geological history, LTHA are easily destroyed during the burial process, and it is difficult to find complete samples. Fortunately, abundant samples of LTHA from the Chang 7 section of the Triassic Yanchang Formation in the Ordos Basin were recently discovered by our team. Their tubular shapes and 
inner and outer walls are fully developed, so they are particularly valuable, they may be fragments and channels of hydrothermal chimneys. They have opened up a new way to study the structural characteristics and growth history of hydrothermal chimneys in continental basins in the Late Triassic. and provide an excellent opportunity for the comparative study of modern and ancient hydrothermal chimneys.

High-quality source rocks have been developed in the Chang 7 Member of the Upper Triassic Yanchang Formation on the southern margin of the Ordos Basin. Previous studies ${ }^{[8,9,10,11,12]}$ have also confirmed the occurrence of hydrothermal activity during the deposition of the source rocks. Based on research about modern hydrothermal deposition and submarine black chimneys, we study the morphology, material composition, structure, mineral characteristics, geochemical characteristics and formation stages of hydrothermal channels, and we compare them with chimney samples from modern ocean floors and continental hydrothermal activity and discuss their geological significance.

\section{Regional Geological Background}

The Ordos Basin is located in Central China. It is a lacustrine sedimentary basin that formed during the Mesozoic. The basin area is approximately $25 \times 10^{4} \mathrm{~km}^{2}[13,14,15]$. Its periphery is surrounded by Cenozoic fault basins. The western part of the basin is a tectonic thrust belt and the Liupan Mountains, and the southern part is the Weihe Basin and the Weibei uplift. The Jinxi flexural belt is located in the eastern part of the basin. The northern part of the basin is adjacent to the Yimeng uplift and the Hetao Basin uplift. The overall contours of the basin form a roughly north-south rectangle (Fig. 1). In the Late Triassic, the basin contained the largest area of lake water, which covered almost the entire basin. Deep lake facies developed on the southern margin of the basin, and thick layers of dark mudstone and oil shale that compose the Chang 7 member of the Yanchang Formation were deposited, with a thickness of up to 100 $\mathrm{m}$. This set of high-quality source rocks has strong hydrocarbon generation and expulsion capabilities and is the main Mesozoic source rock in the basin. According to sedimentary cycles and lithologic combination characteristics, it can be divided into 10 oil layer groups (Chang 10-Chang I) from bottom to top. The Chang 7 section is subdivided into 3 subsections: Chang $7-3$, Chang $7-2$ and Chang $7-1$. During the Chang 7 sedimentation period, the basin subsided, and the depth of the lake increased, reaching a depth of 60-80 $\mathrm{m}$ in the southern part of the basin. The area of the lake basin increased, and a large area of deep water appeared, covering almost the entire Ordos Basin. In addition, during the Late Triassic, hydrothermal deposition at the bottom of the lake ${ }^{[8]}$, interlayers of tuff ${ }^{[16]}$, turbidites ${ }^{[17]}$, deposition of sandy debris flows ${ }^{[18]}$, deposits of seismite, extensive development of sandstone veins and mutations of sporopollen assemblages ${ }^{[13]}$ accumulated that reflect the strong structural characteristics of the basin. In the context of strong tectonic activity in this region, basal ruptures may have been activated $^{[10]}$, which created conditions for the development of LTHA in the basin.

\section{Geological Characteristics Of Hydrothermal Chimneys}


The fragments and channels of the hydrothermal chimney studied in this paper were found in the Chang 7 - 1 section of the Triassic Yanchang Formation in the Z22 well, which is located in the southern part of the Ordos Basin. The strata are dominated by dark siltstones and mudstones, with iron dolomite, carbonates, and thin siliceous rocks. Gravity flows such as sandy debris flows and turbidites are observed, and abundant fossils of animal microorganisms and plant debris are also distributed. In this paper, three typical hydrothermal channels in the Zh22 well were selected for detailed analysis (Fig. 2b,c,f). Numerous polished thin sections from the three channels samples (1551.6, 1551.6-2 and 1574.4) were examined microscopically to determine the mineral contents and textural characteristics of the hydrothermal channels walls. Analyses of the same sections were made with an electron microprobe to accurately determine specific mineral compositions and to document compositional zoning within individual grains and across channels walls from interior to exterior.

$\nabla$ Hydrothermal channels are developed in oil shale and have a columnar shape when viewed in cross section, with many branches converging upward (Fig. 3a,b,c). The results of mineralogical analysis show that the minerals in the hydrothermal channels are mainly pyrite, anhydrite, barite, calcite, and dolomite and small amounts of quartz and albite. The outermost skin of black smokers bears fine-grained pyrrhotite $\left(\mathrm{Fe}_{1-\mathrm{x}} \mathrm{S}\right)$, pyrite $\left(\mathrm{FeS}_{2}\right)$ (Fig. 3d) and dolomite $\left(\mathrm{CaMg}\left(\mathrm{CO}_{3}\right)_{2}\right)$ with textures matching those in mineralogically similar black plume particulate assemblages. Within channels walls, a pyrrhotite-free sulfide and carbonate assemblage of coarser, more euhedral FeS2 (pyrite and/or marcasite), dolomites and calcites is present. These sulfides and carbonates often replace anhydrite outward along crystallographic planes in the sulfate (Fig. 3e). $\otimes$ Observations of the vertical cross section of the hydrothermal channel show that the channel structure of the chimney is clearly visible. The channel is composed of a channel, inner wall, outer wall and surrounding rock. The main channel is associated with branch channels, and the minerals and structures of the channel are zoned (Fig. 2d, e). $\otimes$ The parallel cross section of the hydrothermal chimney channel contains 4 sedimentary layers. The bottom of the hydrothermal channel is composed of dolomite and calcite and develops a chicken bone-like structure (layer 1 in Fig. 2d, layer 1 in Fig. 2e, Fig. 3f); Pyrite layers are distributed on both sides of the hydrothermal channel (layer 2 in Fig. 2d, layer 2 in Fig. 2e, Fig. 2f) and are formed by the precipitation of breccia pyrite supplied by the hydrothermal channel (Fig. 3a). Dolomite and calcite with breccia structure develop in the middle layer of the hydrothermal channel (layer 3 in Fig. 2d, layer 3 in Fig. 2e); dolomite and calcite have a good degree of crystallinity, and the grains develop zoning (Fig. 3h), which is explained as the natural growth of carbonate minerals in the hydrothermal environment. The breccia structure, saddle-like structure, radial structure, etc., often appear at the top of the hydrothermal channel (layer 4 in Fig. 2d, layer 4 in Fig. 2e), which is composed of dolomite, calcite, pyrite and microfauna fossils (Fig. $3 g, i)$. The above characteristics confirm the existence of LTHA, and they record the development process of the LTHA.

\section{Sample Analysis And Experimental Methods}

\section{1 sample collection and processing}


From the bottom layer to the top layer, the researcher collected 11 samples of mudstone, 4 samples of argillaceous siltstone, and 20 samples of hydrothermal sedimentary rock from the Chang $7-1$ section of the Yanchang Formation of the Triassic in the Zh22 well, with a total of 35 samples, in which LTHA were found in samples 1551.6, 15516.-2 and 1574.4. During the sampling process, the influence of the mechanical differentiation on sediment composition and the tendency of sampling differences are minimized or eliminated. The sample collection and processing are described: $\otimes$ Three samples about LTHA were ground into ordinary rock flakes. After observing the sedimentary structure of the rock specimen and the composition, microstructure and fluorescence characteristics of the mineral under the microscope, the samples with complete morphology were selected to be made into electron probe sheets and SEM samples to determine the main elements, mineral components and microscopic mineral structure. $\otimes$ The geochemical composition of pyrite particles, coarse-grained dolomite and coarse-grained calcite was further analysed with LA-ICP-MS. Since the laser beam spot of this method is $36 \mu \mathrm{m}$, which is much larger than that of micro-crystalline minerals and secondary enlarged mineral particles, only coarsegrained mineral particles can be analysed. $\otimes$ For the preparation of SEM samples, according to the needs of the experiment, a cube of $0.5 \times 0.5 \times 0.5 \mathrm{~cm}$ was made. The surface structure of the 6 sections was intact and was not damaged. It was used after being sputtered with gold for conductive treatment. After completing the above work, the rock samples were selected according to the characteristics of the samples and the research needs for the main and trace elements, scanning electron microscopy and other tests.

\subsection{Analysis method}

$\nabla$ A total of 48 sets of data were completed for in situ trace element and rare earth element experiments, which were completed at the State Key Laboratory of Continental Dynamics, Northwest University. using an Agilent 7500 ICP-MS instrument attached to a $193 \mathrm{~nm}$ excimer laser ablation system (Geolas 2005) [12]. All measurements were performed in time-resolved mode with helium as the carrier gas. The carrier flow was optimized to obtain the maximum signal intensity for ${ }^{238} \mathrm{U}+$, while keeping the $\mathrm{ThO}^{+} / \mathrm{Th}^{+}$ratio below $0.5 \%$ and the $\mathrm{U}^{+} / \mathrm{Th}^{+}$ratio close to 1 for the reference glass (SRM 610, National Institute of Standards and Technology) ${ }^{[18]}$.

$\nabla$ The main element was tested using a JXA-8100 electron probe system $\left(15 \mathrm{kv}\right.$, beam $1 \times 10^{-8} \mathrm{~A}$, beam spot 1-5 $1 \mathrm{~m}$ ) and an X-ray energy spectrometer (LINK ISIS300, UK) to analyse the main elemental constituents and contents of the different compositions of hydrothermal minerals, such as iron dolomite and pyrite.

$\nabla$ The mineral characteristics and structure of the rock samples were observed using SEM (Model S-3200, Hitachi, Ltd.) and an environmental SEM (Quanta Model 400, Phillips). The observation range is approximately $1 \mathrm{~cm}^{2}$. A larger range of progressive scans was performed on the target sample (we can see the hydrothermal chimney) and the control sample (no hydrothermal chimney sample). 
$\otimes$ Sulphur isotope analysis of pyrite was completed at the State Key Laboratory of Continental Dynamics, Northwest University. The laser ablation system was manufactured by Resso, model RESOlution S-155. The ArF excimer laser generator produces a $193 \mathrm{~nm}$ deep ultraviolet beam that is focused on the sulphide surface by a homogenized optical path. The diameter of the laser beam spot is generally $33 \mu \mathrm{m}$, the ablation frequency is $10 \mathrm{~Hz}$, and the ablation is performed for 40 seconds. The high-purity helium gas is used as a carrier gas and mixed with argon gas and nitrogen gas to enter the mass spectrometer. The multi-receiver plasma mass spectrometer was manufactured by the Nu Instrument Corporation using the model Nu Plasma II. The ${ }^{34} \mathrm{~S} /{ }^{32} \mathrm{~S}$ ratio of the standard sample and the sample point was obtained by direct test, and the $\delta^{34}$ SCDT value was calculated by the external standard correction (SSB method). The standards used were the international sulphide standard NBS-123 sphalerite and the laboratory internal standard WS-1 pyrite (Fig. 5e).

\section{Results}

The experimental analysis of electron probe, major elements, trace elements, rare earth elements and insitu $S$ isotope of the LTHA samples in the study area has been completed. The specific experimental results are as follows:

\subsection{Electron probe analysis}

The experiment results of electronic probe of the LTHA samples are shown in Table 1. A total of 19 points of the 3 samples were analyzed. The samples are mainly composed of dolomite, calcite, pyrite, siderite, and feldspar (Fig. 4). In the 1551.6, 1574.4 and 1551.6-2 samples, $\mathrm{SiO}_{2}, \mathrm{Al}_{2} \mathrm{O}_{3}, \mathrm{FeO}$ and $\mathrm{CaO}$ are the four most abundant elements. In this study, 19 positions of the hydrothermal channel were selected to complete the electron probe test. The results are shown in the Table 1. The experimental points of sample 1551.6 correspond to the 9 yellow stars in $\mathrm{Fig}$. 2a. The $\mathrm{SiO}_{2}$ contents of points 7 and 8 were $57.255 \%$ and $58.108 \%$, respectively, and the remaining positions contained almost no $\mathrm{SiO}_{2}$. The $\mathrm{Al}_{2} \mathrm{O}_{3}$ content of points 7 and 8 were $34.92 \%$ and $33.91 \%$, respectively, and the remaining positions had very small contents of $\mathrm{Al}_{2} \mathrm{O}_{3}$, ranging from $0.003-0.09 \%$. The $\mathrm{FeO}$ contents of points 2 and 4 were $48.754 \%$ and $45.756 \%$, respectively, and the remaining positions had very small contents of $\mathrm{Al}_{2} \mathrm{O}_{3}$, ranging from $0.86-3.298 \%$. The $\mathrm{CaO}$ contents at points 1, 5, 6 and 9 were $55.696 \%, 55.355 \%, 60.486 \%$ and $58.097 \%$, respectively, and the $\mathrm{CaO}$ content in the remaining positions was small. Other major elements, such as $\mathrm{MgO}, \mathrm{Na}_{2} \mathrm{O}, \mathrm{K}_{2} \mathrm{O}$, $\mathrm{MnO}, \mathrm{TiO}_{2}$ and $\mathrm{P}_{2} \mathrm{O}_{5}$, were rare. Except for point 3 , the content of $\mathrm{SrO}$ was $0.052-0.846 \%$, and the average content was 0.412 . In the first four positions of sample 1551.6-2 (The experimental points correspond to the 5 yellow stars in Fig. 2b), $\mathrm{CaO}$ was the main element, and the value was located at $52.79 \sim 54.824 \%$; the fifth position was pyrite, and the main elements were Fe and S. In sample 1574.4, a total of 5 dolomite single mineral experiments were completed. Here, $\mathrm{CaO}$ was the main element, and the values were located between 37.688 and 44.375 .

\subsection{Trace elements}


In this study, three typical samples about LTHA were selected, and a total of 49 positions were used for in situ trace elemental analysis. The results are shown in Table 2. From the standard spider web map of trace elements (Fig. 6a,c,e,g and i) shows that except for $\mathrm{U}, \mathrm{Nb}, \mathrm{Pb}, \mathrm{Ti}$ and other elements, the content fluctuates greatly, and the other elements have more consistent trends. $\otimes$ The in-situ trace element experiment of sample 1551.6 was completed around three blue lines (the blue lines 123 in Fig. 5 represent different positions of the hydrothermal chimney respectively). Line 1 represents the passage of the hydrothermal chimney. Studies have shown that: the $\mathrm{U}, \mathrm{Pb}$, and $\mathrm{Sr}$ contents are significantly positive, indicating that the material source of the jet channel is complex. Mixed with shell source material; Some points of Eu are significantly positive, and some are weak positive, which explains that the spray channel mineral is formed in a high temperature environment, and the temperature away from the nozzle is lowered. Line 2 represents the top position away from the hydrothermal channel, corresponding to layer 4 in Fig. 2d. Studies have shown that: $U$ and $P$ are significantly abnormal, indicating that the hydrothermal fluid brings nutrients to promote the improvement of the ancient productivity. Line 3 represents the pyrite layer of the hydrothermal channel, corresponding to layer 3 in Fig. $2 \mathrm{~d}$. where $\mathrm{Pb}$ is significantly abnormal, close to 20,000 , and Eu shows a weak positive anomaly. $\otimes$ The in situ trace elemental analysis of sample 1574.4 showed that $\mathrm{U}$ and $\mathrm{Pb}$ were significantly positive and that Eu shows a weak negative anomaly. $\mathbb{V}$ The in situ trace elemental analysis of sample 1551.6-2-1 showed that $U$ and $\mathrm{Pb}$ were significantly positive and that Eu showed a weak negative anomaly. According to REYCN patterns of (k) hightemperature hydrothermal fluids from the Broken Spur vent site, $29^{\circ} \mathrm{N}$ Mid-Atlantic Ridge, and $(\mathrm{L})$ lowtemperature diffuse hydrothermal flow at the TAG hydrothermal mound, $26^{\circ} \mathrm{N}$ Mid-Atlantic Ridge. They all show that Eu is abnormal. In fig. $b$ and $f$ of this study, some samples also show positive abnormalities of Eu.

From the standard REE distribution pattern of chondrite in the sample (Fig. $6 \mathrm{~b}, \mathrm{~d}, \mathrm{f}, \mathrm{h}$ and $\mathrm{j}$ ), it can be seen that the changing characteristics of the curve are basically the same, showing that the fractionation is obvious between the LREE and HREE; thus, the LREE is enriched and the HREE is relatively depleted. $\nabla$ In sample 1551.6, the REE curve at the position of blue line No. 1 is relatively flat, the Eu content at some points shows a positive anomaly, and the Eu content at some points is normal, indicating that the formation temperature of the channel changes. The REE curve at the position of blue line No. 2 is relatively flat, and all points of the Eu content show a weak negative anomaly. The REE curve of the pyrite layer in the No. 3 blue line is relatively flat. Some points of the Eu content show positive anomalies, and some points of the Eu content are normal, indicating that the formation temperature of the channel changes; in addition, the mineral formation temperature near the hydrothermal channel is higher. However, away from the hydrothermal channel, the mineral formation temperatures are low. $\mathbb{Q}$ In sample 1574.4, the curve of LREE is steeper, the curve of HREE is relatively flat, and all points of the Eu content show a weak negative anomaly. $\otimes$ In sample 1551.6-2-1, the curve of LREE is steep, the curve of HREE is relatively flat, and all points of the Eu content show a weak negative anomaly. The REYCN model diagram of the fluid at the vent of the $29^{\circ} \mathrm{N}$ Mid-Atlantic Ridge fracture (Fig. 6k), and the REE model diagram of the TAG low-temperature hydrothermal vent in the Mid-Atlantic Ridge at $26^{\circ} \mathrm{N}$ (Fig. $6 \mathrm{l}$ ), Eu is positive. 
According to the REE patterns of this study (Fig. b and f), some samples show positive abnormalities of Eu.

\subsection{Abnormalities of in situ $S$ isotopes of pyrite}

Traditional $\mathrm{S}, \mathrm{Pb}$ isotope analysis mostly uses single mineral powder samples (bulk analysis). It is difficult to guarantee the purity of single mineral particles, and it is difficult to separate the single mineral samples formed under different genesis. Simultaneously, it is difficult to finely distinguish the ring bands formed under different conditions for the sulphides of the developmental ring structure, so that the test results are often indicating multi-sources ${ }^{[19]}$. Mixed values result in multiple solutions. NanoSIMS is capable of in situ micro-analysis of micron-sized pyrite. It can accurately analyse single mineral particles without destroying the particle structure and has high spatial resolution, which replaces the shortcomings of traditional analytical methods. There are four main sources of sulphur on the earth: (1) mantle sulphur (magma sulphur), $\delta 34 \mathrm{~S}$ value is close to 0 , usually $0 \pm 3 \%$; (2) seawater sulphur, usually characterized by a large positive value; (3) sedimentary sulphur, in which the sulphur isotopic composition varies greatly $(-40 \%$ 50\%o); and (4) mixed sulphur, involving the mixing of two or more different sources of sulphur, in which the level of the sulphur isotope is usually determined by the sulphur isotope composition and mixing ${ }^{[20]}$. A fifth source of sulphur includes the sulphur reduction of hydrogen sulphide and sulphur compounds by bacteria, which is generally less than $-5 \%$. Previous studies have shown that the sulfur isotope values of sulfur-containing compounds in hydrothermal fluids not only depend on the average isotope value of total sulfur in the hydrothermal fluid but also are constrained by physical and chemical conditions, including oxygen fugacity, acidity and alkalinity, and temperature ${ }^{[20]}$. Therefore, the $\delta^{34} S$ value of precipitated sulfide does not simply represent the sulfur isotope composition of the hydrothermal fluid. In general, under low oxygen fugacity and low acidity conditions, the $\delta^{34} S$ value of the hydrothermal fluid is similar to that of the sulfide. In the Late Triassic, the sedimentary environment on the southern margin of the Ordos Basin produced a deep lake facies (Fig. 9), with reducing conditions and low oxygen fugacity ${ }^{[12,14]}$. The hydrothermal fluid was weakly acidic fluid with a low $\mathrm{pH}$ value ${ }^{[8]}$ with sulfur mainly in the form of $\mathrm{H}_{2} \mathrm{~S}$. Therefore, the $\mathrm{d} 34 \mathrm{~S}$ value of pyrite in the study area can approximately represent the sulfur isotope composition of the hydrothermal fluids. We use the following formula ${ }^{[1,20]}$ to estimate the proportion of magmatic sulfur in the hydrothermal fluid in the study area:

$\delta^{34} S \sum S=x \delta^{34} S(A)+\delta^{34} S(B), x+y=1$

where $x$ and $y$ represent the proportion of deep source magma sulfur and sedimentary sulfur, respectively, and $\delta^{34} S \sum S$ represents the sulfur isotope composition of the hydrothermal fluid. The sulphur isotope data of pyrite in the source rocks of the Zh22 well are shown in Table 3. The $\delta^{33} \mathrm{~Sv}$-CDT values of the 33 points ranged from 1.50 to 5.30 , with an average of 4.883 . The $\delta^{34} \mathrm{~Sv}$-CDT value ranged from 7.89 to 10.88 , with an average of 8.388 . The average $d 34 S$ value of breccia pyrite is $8.49 \%$. $\delta^{34} S(A)$ is the sulfur isotope composition of magma, and its value is taken from the sulfide phase value of carbonaceous chondrite $(3.2 \%){ }^{[22]} . \mathrm{d} 34 \mathrm{~S}(\mathrm{~B})$ is the $\delta^{34} \mathrm{~S}(\mathrm{~B})$ value of formation sulfur, which is the average sulfur isotope 
value $(5.37 \%$ ) of framboidal pyrite in the Chang 7 - 3 sub-member of the Triassic Yanchang Formation ${ }^{[8]}$. The value of $\mathrm{x}$ is calculated to be 0.943 . Therefore, the magmatic sulfur in the hydrothermal fluids in the study area accounted for approximately $94.3 \%$, and the remaining $5.7 \%$ was mixed with sediment sulfur or lake water sulfur.

\section{Discussion}

\subsection{Identification of the cause of LTHA}

Predecessors have carried out detailed studies on hundreds of active hydrothermal chimneys and obtained preliminary important information on the geometry, geological characteristics, internal structure, and mineral composition of the chimneys, which can also be used as an effective method to distinguish LTHA in the geological record ${ }^{[23]}$. Through comparative studies, the mineral composition and structure of the LTHA in this paper are very similar to those reported in previous studies on modern continental and oceanic hydrothermal chimneys. $\otimes$ The channels of the hydrothermal chimneys found in the study area are similar in appearance to the drainage structure of the sedimentary rocks, but the two are essentially different. The drainage structure is mostly found in fine sandstone and black mudstone. The planes form irregular polygons, similar to the cracks on a turtle shell. The cracks formed by the drainage structure are limited to the layer and the irregular mesh structure. The sandstone in the lower part of the vertical section is liquefied, and the upper mudstone is located within fine veins and finally penetrates to the top surface of the mudstone to complete the discharge (Fig. 7i). The jet channel in Fig. $2 \mathrm{e}$ is filled with calcite and dolomite crystals; a large number of radial and saddle-like dolomite, euhedral pyrite and elongated anhydrite crystals have developed around this area; the top consists of a flower-like calcite structure, and there are cryptocrystalline structures with stacked cone-shaped, leaf-like and harbor-like shapes. These structures are related to hot air waves at the bottom of the lake. $\otimes$ The most significant structural feature of modern hydrothermal chimneys is that both the section perpendicular to the chimney and the section parallel to the chimney show zoning. The former is manifested as the zoning of the channel, the inner wall and the outer wall; the latter is often manifested as the formation of a dendritic shape in the upper part of the chimney, retaining the spout structure. The phenomenon of chimney merging or branching is very common, and multiple chimneys frequently cluster to form complex shapes. These include the hydrothermal chimney from the Geological Museum in South Africa (Fig. 7d), the TAG hydrothermal mound (Fig. 7h), and the Brothers submarine volcano (Fig. 7a, b and c). The hydrothermal channels in this study (Fig. $7 \mathrm{~g}$ ) are similar in structure to hydrothermal chimneys from modern oceanic environments, so the research method of modern oceanic hydrothermal chimneys is applied. $\otimes$ On the horizontal section, modern hydrothermal chimneys often show concentric circles or complex mineral zoning ${ }^{[7]}$. The outer wall of the chimney is composed of anhydrite, dolomite, calcite and pyrite. The inner wall is often composed of coarse-grained sphalerite, pyrite, and anhydrite. The plate-like minerals grow vertically on the inner wall and are arranged in a concentric shape and radiate outward. The rock mineral combination of the black chimney in North China is siliceous rock and pyrite + anhydrite (Fig. 7j). Hydrothermal 
dolomite developed in the mining area of Sardinia, Italy (Fig. 7e); the radial structure of dolomite is developed in the hydrothermal area of North Island, New Zealand (Fig. 7f).

On the basis of research on the structure, petrology, mineralogy, and geochemical characteristics of the hydrothermal channel and the source of the $S$ component in breccia pyrite, we have identified the mechanism of the LTHA samples. Generally, hydrothermal activity related to chimneys generates abundant element sources for minerals. After the deposition of hydrothermal substances, the abundances of elements in the sediments show anomalies, and they spread around the nozzle ${ }^{[4]}$. The rocks formed are defined as hydrothermal sedimentary rocks, which are the product of precipitation after the hydrothermal fluid is ejected from the bottom of the sea/lake and interacts with the sea/lake water ${ }^{[24]}$. Previous researchers have established a systematic and multi-index coexistence judgment criterion for hydrothermal deposition through a large amount of research on marine hydrothermal deposition, and a geochemical discrimination diagram is one of the methods used. Here, the $\mathrm{Fe}-\mathrm{Mn}-(\mathrm{Cu}+\mathrm{Co}+\mathrm{Ni}) \times 10$ triangle (Fig. 8b) ${ }^{[25]}$ and the $\mathrm{SiO}_{2} /\left(\mathrm{K}_{2} \mathrm{O}+\mathrm{Na}_{2} \mathrm{O}\right)-\mathrm{MnO} / \mathrm{TiO}_{2}$ diagram (Fig. 8a) $)^{[26]}$ are successfully applied to the identification of terrestrial hydrothermal deposition ${ }^{[10,27]}$. The study area in this paper is characterized by typical lacustrine hydrothermal deposition. Therefore, this paper refers to the geochemical discriminant diagrams for hydrothermal sedimentary rocks to support the formation of LTHA. In the $\mathrm{SiO}_{2} /\left(\mathrm{K}_{2} \mathrm{O}+\mathrm{Na}_{2} \mathrm{O}\right)-\mathrm{MnO} / \mathrm{TiO}_{2}$ discrimination diagram of the sediment (Fig. 8a), all projection points of the 1551.6 sample plot in the hydrothermal deposition zone; most of the projection points of the 1574.4 sample and the 1551.6-2 sample plot in the hydrothermal deposition zone, and a small number of the projection point plot close to the hydrothermal-rich deposition zone. In the Fe-Mn- $(\mathrm{Cu}+\mathrm{Co}+\mathrm{Ni}) \times 10$ discrimination diagram (Fig. 8b), some projection points of the 1551.6 sample plot in the hydrothermal deposition area, some projection points plot in the hydrothermal deposition area of the Red Sea, and there are 3 projection points that plot in the eastern Pacific Ocean hydrothermal sedimentation area. Some projection points of the 1574.4 sample plot in the hydrothermal deposition area, and some projection points plot in the hydrothermal deposition area of the Red Sea; some projection points of the 1551.6-2 sample plot in the hydrothermal deposition area of the Red Sea, and other projection points plot close to the hydrothermal-rich deposition zone.

\subsection{Formation and growth of hydrothermal chimneys}

In the Chang 7 depositional period of the Triassic Yanchang Formation, the Ordos Basin had the characteristics of frequent event sedimentation, strong tectonic activity and activation of basement faults, which created favorable conditions for hydrothermal jet activity ${ }^{[8]}$. According to the petrological and mineralogical characteristics of hydrothermal chimneys in the study area, we established a hydrothermal chimney formation model for the area (Fig. 2a). There are two main stages experienced by the hydrothermal chimney in the study area. $\otimes$ The chimney walls are initially constructed upward from the sea floor by anhydrite precipitation from seawater. The anhydrite precipitates out of the seawater, forming a structure with anhydrite as the first main mineral. Throughout the hot, active life of the chimney, anhydrite continues to build the chimney walls upward and outward at the interface between the 
chimney and seawater. Metastable pyrrhotite precipitated at the chimney exterior is dissolved and reprecipitated as pyrite when the exterior skin becomes incorporated within the chimney wall by the outward accretion of anhydrite. The anhydrite of the hydrothermal chimney in the study area has a relatively complete crystal form, which is elongated under SEM (Fig. 3e). In addition, the precipitation of anhydrite causes the outer wall of the chimney body to usually have high calcium and strontium contents (Table 2). $\mathbb{\|}$ In the formation stage of sulfide and carbonate, due to the formation of the anhydrite wall of the hydrothermal chimney, which prevents direct contact between the hydrothermal fluid and lake water, dolomite, calcite and Cu-Fe-Zn sulfides begin to precipitate in all directions in the chimney and replace the anhydrite. This introduces stage II, which is dominated by carbonate and sulfide precipitation. The chimney at this point is growing upward (by precipitation of anhydrite), inward (by precipitation of carbonate and Cu-Fe sulfides) and outward (by anhydrite accretion and subsequent replacement of anhydrite by carbonates). During this process, deep magmatic-hydrothermal fluid continues to flow up to the bottom of the lake basin. Both the temperature and the pressure decrease sharply to much lower values than the environmental conditions inside the magma channel. Therefore, the magmatichydrothermal fluid reacts with the cold water, and the "blasting" effect occurs, causing the first crystallized minerals to break into angular shapes and radial shapes (Fig. $3 \mathrm{~g}$ ), and then accumulate near the hydrothermal chimney. $\otimes$ We also found abundant biological fossils around the hydrothermal channels (Fig. 3i). All fossils have been destroyed and are associated with hydrothermal dolomite. A

previous study ${ }^{[14]}$ explained that the creatures living around the hydrothermal channels suffered a disaster, died and were quickly buried to form fossils. The distal deposits of the hydrothermal channels are interbedded dolomite and mudstone (Fig. 3i). The explanation is that at a location far from the hydrothermal chimney, due to the intermittent activity of the hydrothermal fluid, terrigenous clastic deposition and hydrothermal deposition alternately occur ${ }^{[28,29]}$

\subsection{The environmental indications and petroleum significance of the LTHA}

Modern black chimney research in the ocean shows that with the waning and end of hydrothermal activity and the effect of seawater dynamics, the black chimney body undergoes continuous erosion and disintegration; in addition, unstable components are dissolved, and eventually, a sulfide deposit is formed. In contrast to the long history of geology, the life span of a black chimney on the ocean floor after its formation " is generally short, which is only a part of the sulfide depositional formation process ${ }^{[30]}$. Therefore, marine and lacustrine hydrothermal chimneys, especially large-scale hydrothermal chimneys, are difficult to preserve during geologic history. The hydrothermal chimneys from the Chang 7 Member of the Triassic Yanchang Formation in the Ordos Basin are mainly on the scale (diameter, height) of a few centimeters to tens of centimeters in size, corresponding to the small-scale chimneys and their top nozzles in modern submarine chimneys. This is also a common feature of hydrothermal activity zones in other parts of the world (Slave Point in Canada, Sardinia in Italy) ${ }^{[31,32]}$. From the morphological comparison perspective, the Ordos Basin retains relatively complete paleo-hydrothermal nozzles, which are columnar with bifurcated channels. This arrangement is related to the low-temperature hydrothermal migration rate and the geothermal gradient in the continental rift. From the horizontal bedding developed 
in the oil shale in the study area, the hydrodynamic conditions at the bottom of the lake were weak. Hydrothermal channels are quickly buried and preserved by sediments after the growth and eruption stop. These are the reasons why hydrothermal chimneys of different scales are widely retained in this area with different enrichments.

The target layer with the LTHA is located in the Chang 7 section of the Triassic Yanchang Formation in the Ordos Basin and is a high-quality source rock in the study area. The traditional view is that this set of high-quality source rocks is a dark mudstone of the deep lake facies, which is related only to normal lake deposition. Some researchers ${ }^{[8.10,18]}$ have suggested that hydrothermal activity promotes the formation of high-quality source rocks. Hydrothermal activity not only provides thermal energy to promote the maturation of hydrocarbons but also causes the convection and circulation of water, bringing bacteria and minerals from the bottom of the lake to the surface water body, thereby promoting algae reproduction and increasing biological productivity. These conditions promote the formation of highquality source rocks in the Ordos Basin(Fig. 9). In addition, hydrothermally formed petroleum has been discovered in the Gulf of Guaymas Basin ${ }^{[33]}$, the Escanaba Trough ${ }^{[34]}$, and the Okinawa Trough ${ }^{[35]}$. These findings provide a 'natural laboratory' ${ }^{[36]}$ that not only sheds light on the petroleum generation process and the behavior of petroleum in high-temperature fluids but also provides a new perspective for the study of hydrocarbon organic matter sources and genesis. The study of hydrothermal chimneys in lacustrine oil shale will help deepen understanding of the development mechanism of source rocks in continental basins and lay a foundation for further research on lacustrine hydrothermal petroleum.

\section{Conclusion}

The petrology, mineral assemblage, structure, geochemistry and isotopic characteristics of the samples show that there are lacustrine LTHA in the Chang 7 member of the Triassic Yanchang Formation in the Ordos Basin.

The formation of the hydrothermal channels involved two stages and the formation of mineral zoning across the walls of these structures throughout two major growth phases: a sulfate-dominated stage and a carbonate and sulfide replacement stage. In the second stage, the hydrothermal fluid migrating outward from the center of the channel dissolved and replaced anhydrite with carbonate and sulfide minerals.

In the Late Triassic, the lake in the Ordos Basin had a great water depth, weak hydrodynamic conditions at the bottom of the lake, and an anoxic environment. The hydrothermal channels were quickly buried and preserved by sediments after the growth and eruption stopped. The hydrothermal channels are distributed in the black rock series in the center of the lake basin, which is a high-quality source rock. The study of hydrothermal chimneys in high-quality source rocks has provided new context for further understanding the development of petroleum.

\section{Declarations}


Acknowledgement:

Thanks to the lecturer Hai Zhou, School of Earth Sciences and Resources, Chang'an University for guiding and helping me in the field.

\section{Declaration of conflicting interests $\square$}

The author(s) declared no potential conflicts of interest with respect to the research, authorship, and/or publication of this article.

\section{Fundings $\square$}

Co-funded by General Program of the National Natural Science Foundation of China (No.41641018). Education Department of Shaanxi Province (20JK1011).

\section{References}

1. Tivey M K, Delaney J R. Growth of large sulfide structures on the Endeavour Segment of the Juan de Fuca Ridge. Earth Planet Sci Lett, 77: 303 317. (1986). Doi.org/10.1016/0012-821X(86)90142-1

2. Lutz R A, Shank T M, Fornari D J, et al. Rapid growth at deep sea vents. Nature, 371: 663 664. (1994).Doi.org/10.1038/371663a0.

3. Haymon, R.M. \& M. Kastner. Hot spring deposits on the East Pacific Rise at $21^{\circ} \mathrm{N}$ :Prelimlnary descrlption of mineralogy and genesis, Earth Planet.Sci.Letter. 53, 363-381. (1981).Doi.org/10.1016/0012-821X(81)90041-8.

4. Rona P.A., Klinkhammer G., Nelsen T A, et al. Black smokers $囚$ massive sulphides and vent biota at the Mid-Atlantic Ridge, Nature, 321 (6065) : 33-37. (1986). Doi.org/10.1038/321033a0.

5. Herzig P. M., Becker K. P., Stoffers P., et al., Hydrothermals silica chimney fields in the Galapagos spreading center at $56^{\circ} \mathrm{W}$, Earth planet. Sci. Letter, 89, 261-272.(1988).Doi.org/10.1016/0012821X(88)90115-X.

6. Kelly D.S.,Karson J.A.,Blackman D.K. An off-axis hydrothermal vent field near the mid-atlantic Ridge at $30^{\circ} \mathrm{N}$, Nature, $412: 145-149 .(2001)$. Doi: 10.1038/35084000

7. Charlou, J.L., Donval, J.P. Fouguet.Geochemistry of high $\mathrm{H} 2$ and $\mathrm{CH} 4$ vent fluids issuing from ultramafic rocks at the Rain-bow hydrothermal field(36¹4'N,MAR).Chemical Geology,191(4): 345359. (2002). http://www.doc88.com/p-3985230490902.html.

8. Zhang, W. Z., Yang, H., Jie, L., \& Yang, Y. Lake bottom hot water activity and its impact on the development of high-quality source rocks: A case study of Chang 7 source rocks in the Ordos Basin. Petroleum Exploration and Development, 37 (4), 424-428. (2010). Doi: 10.1016/S18763804(10)60043-2.

9. He C., Ji LM, et al. (2016). Characteristics of hydrothermal sedimentation process in the Yanchang Formation, south Ordos Basin, China: Evidence from element geochemistry. Sedimentary Geology, 
345 (2016) 33-41. Doi.org/10.1016/j.sedgeo.2016.09.001.

10. You J. Y., Liu Y.Q., Zhou D.W., Zheng Q.H., Vasichenko K. \& Chen Z. B. Activity of hydrothermal fluid at the bottom of a lake and its influence on the development of high-quality source rocks: Triassic Yanchang Formation,southern Ordos Basin, China. Australian Journal of Earth Sciences. 67(1):115128.(2019). https://doi.org/10.1080/08120099.2019.1612783.

11. You J.Y., Liu Y. Q., Song S. S., Zhou D. W., Yang Y. Y. In situ S isotope analysis and source tracing of pyrite from lacustrine hydrothermal sedimentary rocks: the Chang 7-3 sub-member, Triassic Yanchang Formation, Ordos Basin. Australian Journal of Earth Sciences. (2020a). https://doi.org/10.1080/08120099.2021.1828165.

12. You J.Y., Liu Y.Q., Zhou D.W., et al. Characteristics and controlling factors of LORS from the Chang 73 section of the Triassic Yanchang Formation in the Ordos Basin, Journal of Petroleum Science and Engineering. 197C,108020. (2021). https://doi.org/10.1016/j.petrol.2020.108020.

13. Liu, C., Zhao, H., Wang, F., \& Chen, H. . Attributes of the Mesozoic structure on the west margin of the Ordos Basin. Acta Geologica Sinica, 79 (6), 738-746. (2005). Doi:10.3321/j.issn:00015717.2005.06.003.

14. You J.Y., Liu Y.Q., Li Y. X. et al. Discovery and significance of ancient cod fossils in hydrothermal fluid deposition areas: a case study of Chang 7-3 from the Triassic Yanchang Formation in the Ordos Basin, Historical Biology, (2020b). https://doi.10.1080/08912963.2020.1769091.

15. You J. Y., Liu Y. Q., Zhang X. L. et al. Establishment and significance of ancient lake ecosystems in the Mesozoic-Evidence from coprolite from the Chang 7 section of the Upper Triassic in the Ordos Basin, China. Historical Biology, (2020c). https://doi.org/10.1080/08912963.2020.1840564.

16. Qiu, X. W., Liu, C. Y., Mao, G. Z., Deng, Y., Wang, F. F., \& Wang, J. Q. . Major, trace and platinum-group element geochemistry of the Upper Triassic nonmarine hot shales in the Ordos basin, Central China. Applied Geochemistry, 53, 42-52. (2015).Doi: 10.1016/j.apgeochem.2014.11.028.

17. Wang Q.C.,Li W.H.,Zhao H.,Wang L.,Qu H.J. Depositional feature of the Chang 1 of Yanchang Formation in Jingbian-AnsaiArea, Ordos Basin, China. Journal of Northwe st University (Natural Science Edition).36(1):107-110.(2006). Doi:10.16152/j.cnki.xdxbzr.2006.01.026.

18. Bao Z.A., Yuan H.L., Zong C.L., et al.Simultaneous Determination of Trace Elements and Lead Isotopes in Fused Silicate Rock Powders Using a Boron Nitride Vessel and fsLA-(MC)-ICP-MS. J. Anal. At. Spectrom., 31, 1012-1022. (2016). Doi.org/10.1039/C5JA00410A.

19. Chen Q.H.,Li W.H.,Zhao H.G.,Cui J.P. \& Liang J.W. Sequence analysis of the Triassic Yanchang Formation in the area of Ansai. Journal of Northwest University (Natural Science Edition).36(5):785788.(2006). Doi:10.16152/j.cnki.xdxbzr.2006.05.024

20. Ohmoto H. and Rye R.O. Isotopes of sulfur and carbon // Barnes H.L., Geochemistry of Hydrothermal Ore Deposits. New York. John Wiley and Sons: 509-567.

(1979).https://biblio.co.uk/book/geochemistry-hydrothermal-ore-deposits-barnes-hl/d/1246863454

21. Zhao, J., Liang, J. L., Li, J., Ni, S. J., \& Xiang, Q. R. (2018). Genesis and metallogenic model of the Shuiyingdong gold deposit, Guizhou Province: Evidence from high-resolution multi element mapping 
and in situ sulfur isotopes of Au-carrying pyrites by NanoSIMS. Earth Science Frontiers, 25(1), 157167. https://doi.org/10.13745/j.esf.yx.2018.01.011

22. Zheng, Y. F., \& Chen, J. F. (2000). Stable isotope geochemistry (pp.193-247). Science Press. (in Chinese)

23. Li J.H., Niu X. L., Feng J. The Identification of the Fossil Black Smoker Chimney and Implication for Scientific Research. Advance in Earth Sciences, 19(1):18-26. (2004). http://www.cqvip.com/read/read.aspx?id=9021222.

24. White, D. E. Thermal waters of volcanic origin. Geological Society of America Bulletin, 68(12), 16371658.(1957).Doi: 10.1130/0016-7606(1957)68[1637:TWOVO]2.0.CO;2.

25. Bostrom K.,Rydell H.,Joensuu O. Langbank:An exhalative sedimentary deposit. Econ Geol, 74(5):1002-1011. (1979). Doi: org/10.2113/gsecongeo.74.5.1002.

26. Crerar, D. A., Namson, J., Chyi, M. S., Williams, L., \& Feigenson, M. D. Manganiferous cherts of the Franciscan assemblage. 1. General geology, ancient and modern analogs, and implications for hydrothermal convection at oceanic spreading centers. Economic Geology, 77, 519-540. (1982). Doi: 10.2113/gsecongeo.77.3.519

27. Qi H.W., Hu R.Z., Su W.C. (2004). Genesis of continental hydrothermal sedimentary genesis siliceous rocks and superlarge antimony deposits:Taking Linfen deposit as an example. Chinese Science: Series D,33(3):236-246.Doi: 10.1360/02yc0141.

28. Liu Y.Q., Li H., Zhu Y.S., Hu T., Fu G.B., Liu H.F., Zhou X.H., Zheng C.Y. \& Fan T.T. Permian Lacustrine Eruptive Hydrothermal Dolomites, Santanghu Basin, Xinjiang Province. Acta Sedimentologica sinica. 28(5): 862-868.(2010) Doi:10.14027/j.cnki.cjxb.2010.05.003.

29. Zhong, D.K., Jiang, Z.C., Guo, Q., Sun, H.T. A review about research history, situation and prospects of hydrothermal sedimentation. Journal of Palaeogeography, 17, 285-296. (2015).

Doi:10.7605/gdlxb.2015.03.024.

30. Hoffert, M., A. Perseil et al. Hydrothermal deposits sampled by diving saucer in Transform fault " $A$ " near $37^{\circ} \mathrm{N}$ on the Mid-Atlantic Ridge, Famous area, Oceanal. Acta, 1,73-56.(1978).

31. Bonia M., Iannacea A., Bechstadtb T., Gasparrinib M. Hydrothermal dolomites in SW Saedinia(Italy) and Cantabria (NW Spain): evidence for late to post Variscan widespread fluid flow events. Journal of Geochemical Exploration, 69-70 : 225-228. (2000). Doi:10.1016/S0375-6742(00)00020-0.

32. Al-Aasm,I.S.Origin and characterization of hydrothermal dolomite in the Western Canada Sedimentary Basin[J]. Journal of Geochemical Exploration, 2003, 78-79: 9-15.

33. Simoneit B.R.T.,Lonsdale P F. Hydrothermal petroleum in mineralized mounds at the seabed of Guaymas Basin. Nature, 295: 198-202. (1982). Doi.org/10.1038/295198a0

34. Kvenvolden, K.A., Rapp J.B., Hostettler, F.D., J.David K., George E. Claypool Organic geothermometry of petroleum from Escanaba Trough, offshore northern California.Organic Geochemistry, 13(1-3) :351-355.(1988) Doi.org/10.1016/0146-6380(88)90055-1.

35. Yamanaka T., Sakata S.,Abundance and distribution of fatty acids in hydrothermal vent sediments of the western Pacific Ocean. Organic geochemistry, 2004, 35 (5): 573-582 
36. Simoneit B.R.T. ,Petroleum generation in submarine hydrothermal system: an update. The Canadian Mineralogist, 26: 826ه840.(1988). https://citeseerx.ist.psu.edu/viewdoc/download? doi=10.1.1.512.6160\&rep=rep1\&type=pdf

37. Michael Bau, Peter Dulski. Comparing yttrium and rare earths in hydrothermal fluids from the MidAtlantic Ridge: implications for $Y$ and REE behaviour during near-vent mixing and for the YrHo ratio of Proterozoic seawater. Chemical Geology, 155:77-90.(1999). (No Doi)

38. Berkenbosch H. A. De Ronde C. E. J. Gemmell J. B. et al. Mineralogy and Formation of Black Smoker Chimneys from Brothers Submarine Volcano, Kermadec Arc. Economic Geology, 107:1613-1633. https://pubs.geoscienceworld.org/segweb/economicgeology/articlepdf/107/8/1613/3469765/1613-1633.pdf

39. Yang Y.Y.,Liu Y.Q.,Zhou D.W.,Jiao X.,Yue Z.Q.,Qiao J.H. Petrological Features and Geological Significance of Acid Volcanic Rock at the Early Diagenesis Stage: A case study of modern volcanic crater deposits in the Waiotapu geothermal area,Taupo Volcanic Zone,North New Zeal, Acta Sedimentologica sinica, 37(3):469-476.(2019).Doi:10.14027/j.issn.1000-0550.2018.151.

40. Petersen á P. M. Herzig á M. D. Hannington. Third dimension of a presently forming VMS deposit: TAG hydrothermal mound, Mid-Atlantic Ridge, $26^{\circ} \mathrm{N}$. Mineralium Deposita, 35: 233-259. (2000).Doi:10.1007/s001260050018.

41. Zhou Y., Zhang Z., Xu H. Soft deformation structure characteristics of sediments in Lingshan Island, Marine Geology Frontise, 31(4):43-53. (2015). Doi:10.16028/j.1009-2722.2015.04007.

\section{Tables}

Due to technical limitations, tables xlsx are only available as a download in the Supplemental Files section.

\section{Figures}




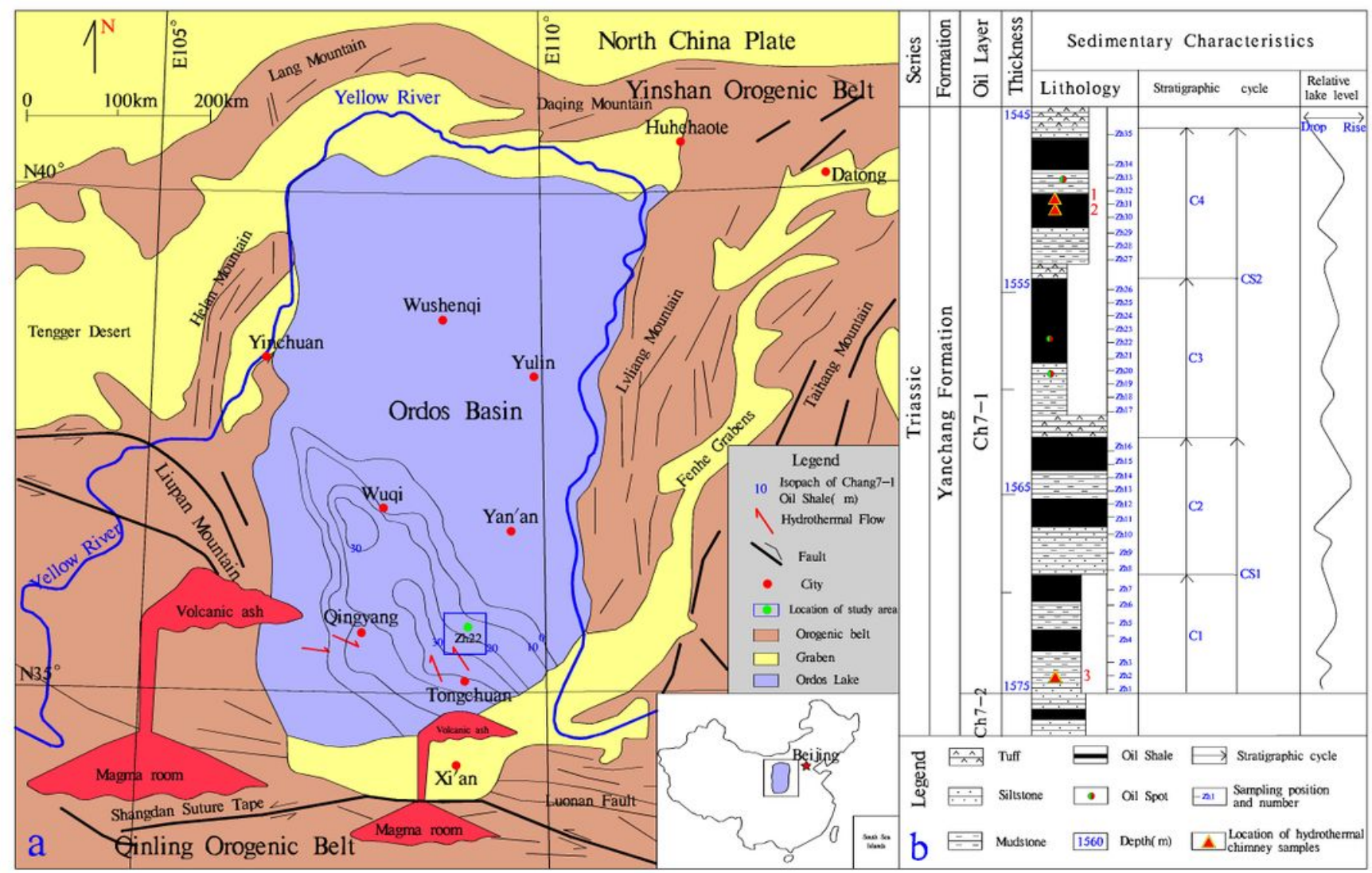

\section{Figure 1}

Regional geological map of the Ordos Basin and stratigraphic column with sampling positions. Note: The designations employed and the presentation of the material on this map do not imply the expression of any opinion whatsoever on the part of Research Square concerning the legal status of any country, territory, city or area or of its authorities, or concerning the delimitation of its frontiers or boundaries. This map has been provided by the authors. 


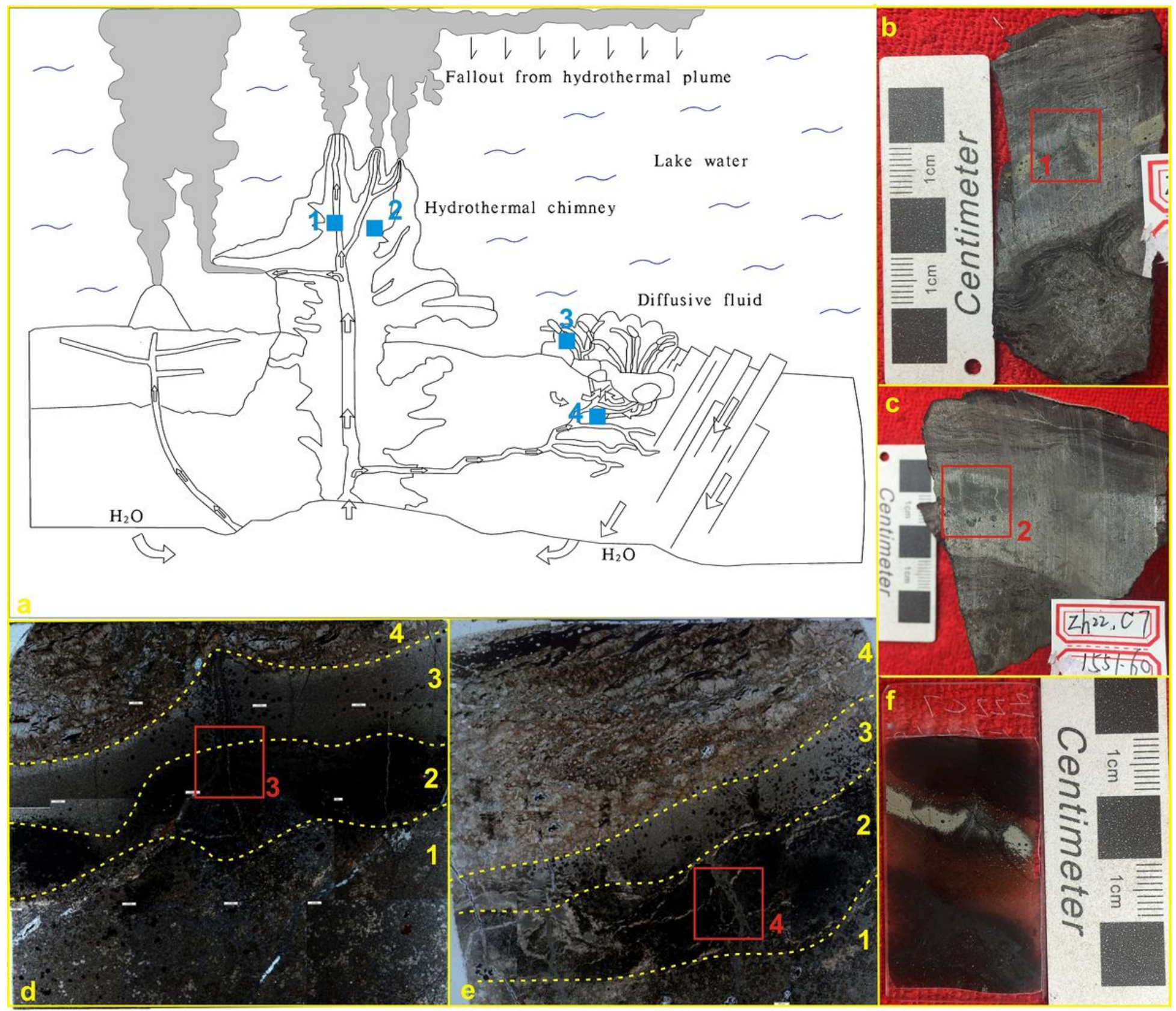

Figure 2

Characteristics of hydrothermal channel in the study area a Sketch of typical hydrothermal chimney b. Hydrothermal channel, $6 \mathrm{~cm} \times 4 \mathrm{~cm}$, sample No. 1551.6, Position 1 from Fig. a. c. Hydrothermal channel, $7 \mathrm{~cm} \times 6 \mathrm{~cm}$, sample No. 1551.6-2, Position 4 from Figure a. d. Enlarged view of the No. 1 red frame in panel $b$, in which layer 1 is dolomite with a radial structure, layer 2 is pyrite, layer 3 is a dolomite + calcite layer, and layer 4 is calcite + dolomite + anhydrite + animal microfossils. $2.5 \mathrm{X}$ magnification, with crosspolarized light. e. Enlarged view of the No. 2 red frame in panel c, in which layer 1 is calcite + dolomite + anhydrite with a radial structure, layer 2 is pyrite, layer 3 is a dolomite + anhydrite layer, layer 4 is calcite + 
dolomite + anhydrite + animal microfossils. at 2.5X magnification, with cross-polarized light. f. Thin slices of hydrothermal channel samples.
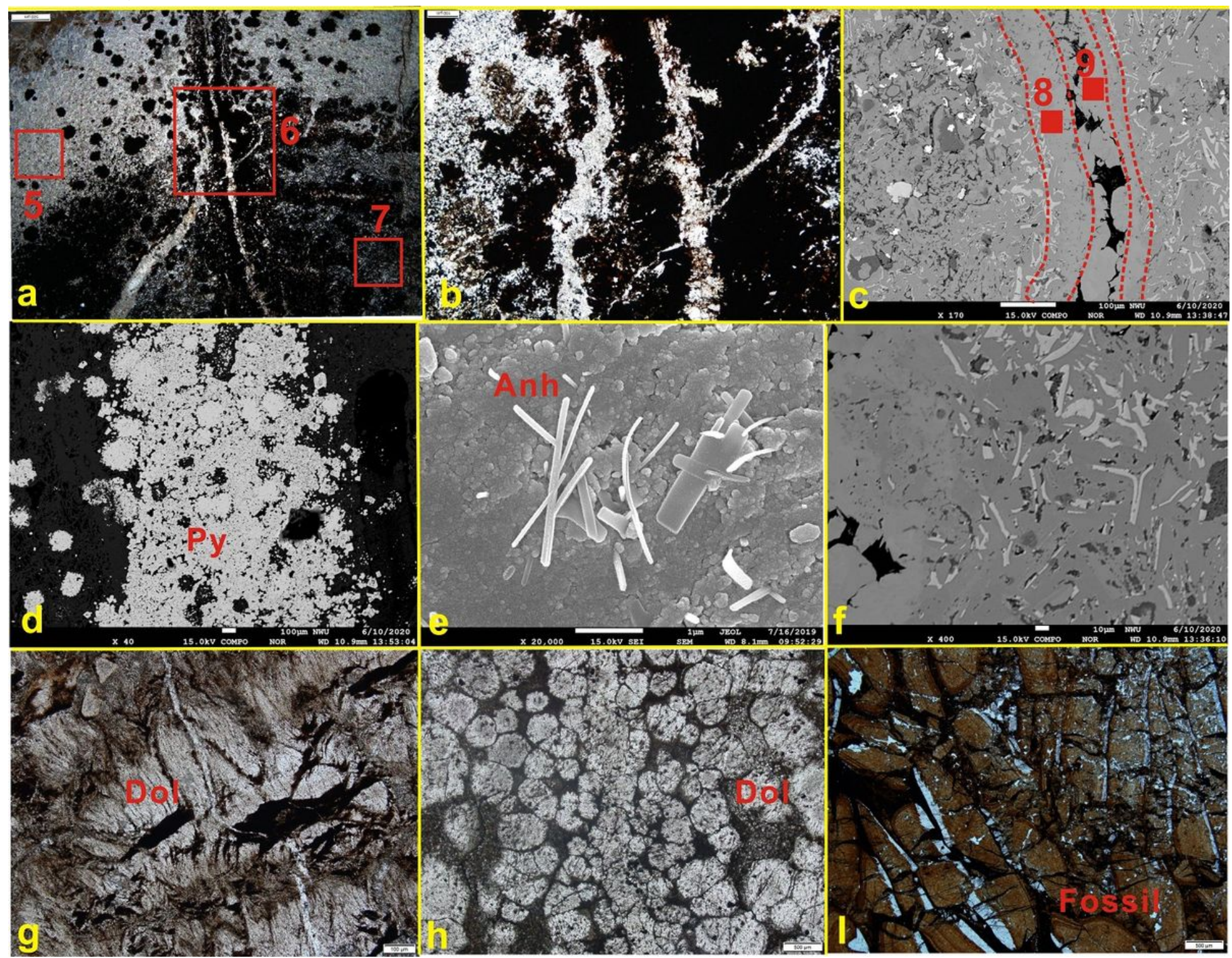

Figure 3

Microscopic photo of hydrothermal channel a. Enlarged view of the No. 3 red frame in Fig. 2d, hydrothermal channel, 2.5X, cross-polarized light. b. Enlarged view of the No. 6 red frame in Fig.a, hydrothermal channel, 10X, cross-polarized light. c. Enlarged view of the No. 6 red frame in Fig. a, hydrothermal channel, BSE. d. Enlarged view of the No. 9 red frame in Fig. c, pyrite, BSE. e. Enlarged view of the No. 8 red frame in Fig. 8, anhydrite with long strip, SEM. f. The bone-like structure in Fig. c, BSE. g. Enlarged view of the No. 5 red frame in Fig. a, the radial structure of calcite, 2.5X, cross-polarized light. $h$. Enlarged view of the No. 2 red frame in Fig. 2a shows that the breccia dolomite develops a ring zone, 2.5X, cross-polarized light. i. Microfauna fossils deposited in No. 3 red frame in Fig. 2a. 


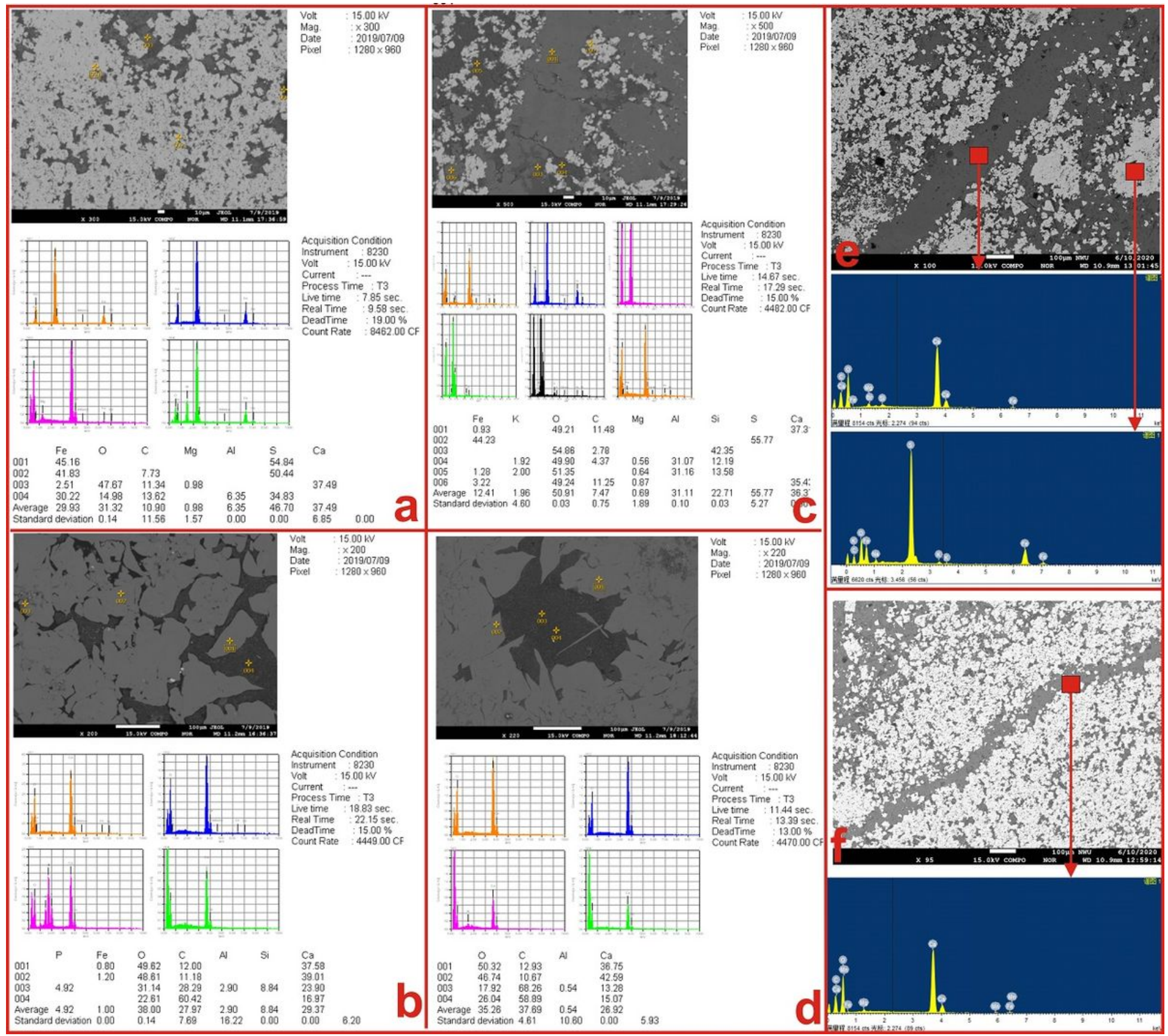

\section{Figure 4}

Images of SEM and EDS data for minerals in the study area a. EDS data for Fig. 2i, white matter is pyrite. b. EDS data for Fig. 2l, calcite. c. EDS data for Fig. 2g, pyrite + iron dolomite + quartz. d. EDS data for Fig. $2 \mathrm{l}$, calcite. Panels e and $\mathrm{f}$ show that the hydrothermal channel is composed of dolomite and pyrite. 


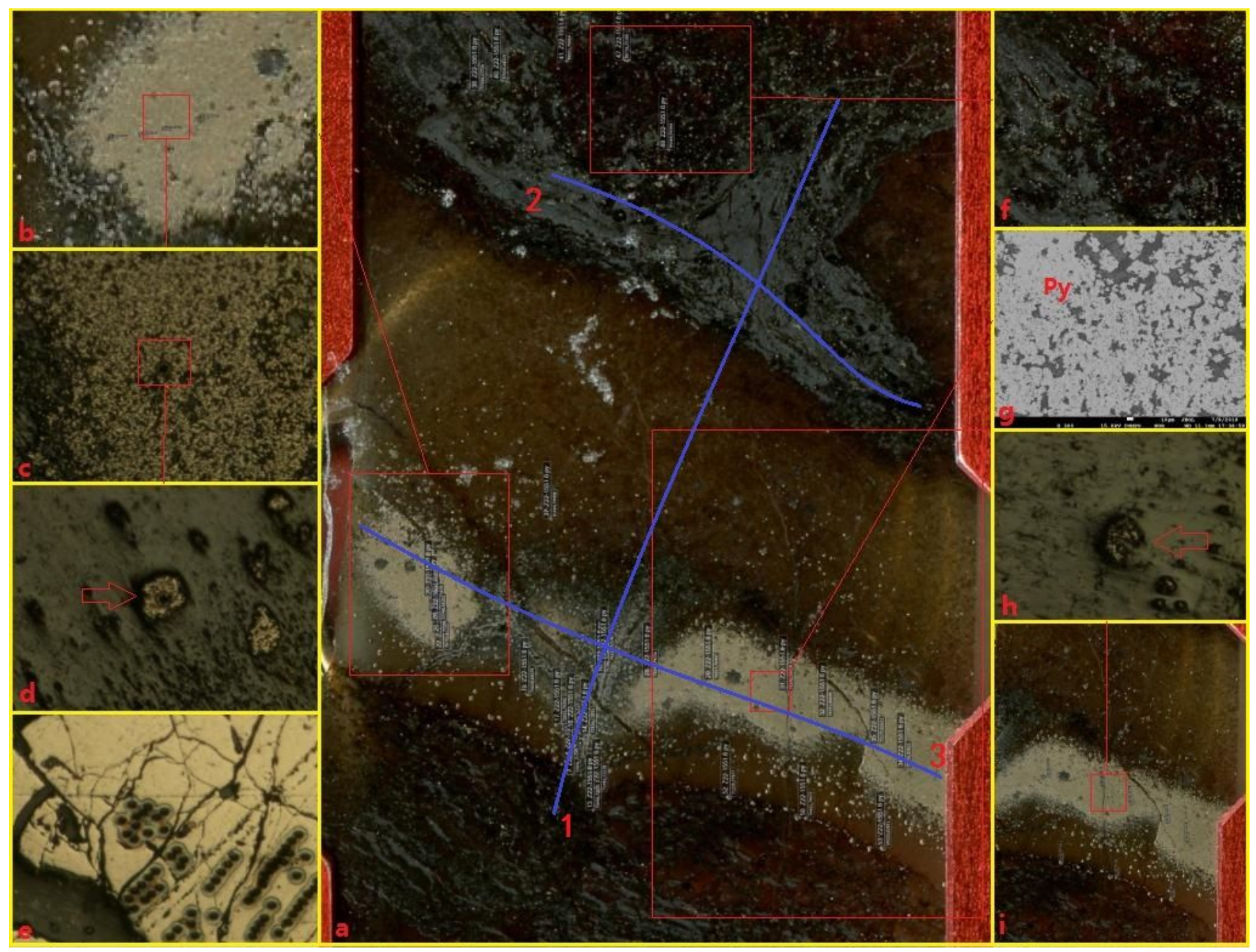

Figure 5

Analytical points for in situ trace elements and sulfur isotopes around pyrite in the hydrothermal channel a. Macroscopic photograph of the hydrothermal channel and experimental point, where the three blue lines indicate the positions of the in situ trace elements. b. Partially enlarged photograph of panel a. c. Partially enlarged photograph of panel b. d. Partially enlarged photograph of panel c. e. Standard sample of pyrite from the State Key Laboratory of Continental Dynamics, Northwest University. f. Partially enlarged photo of the red frame in panel a. g. Backscattered election image of panel a at 130X magnification. h. Partially enlarged photograph of panel i. i. Partially enlarged photograph in the red box at the right of panel a. 

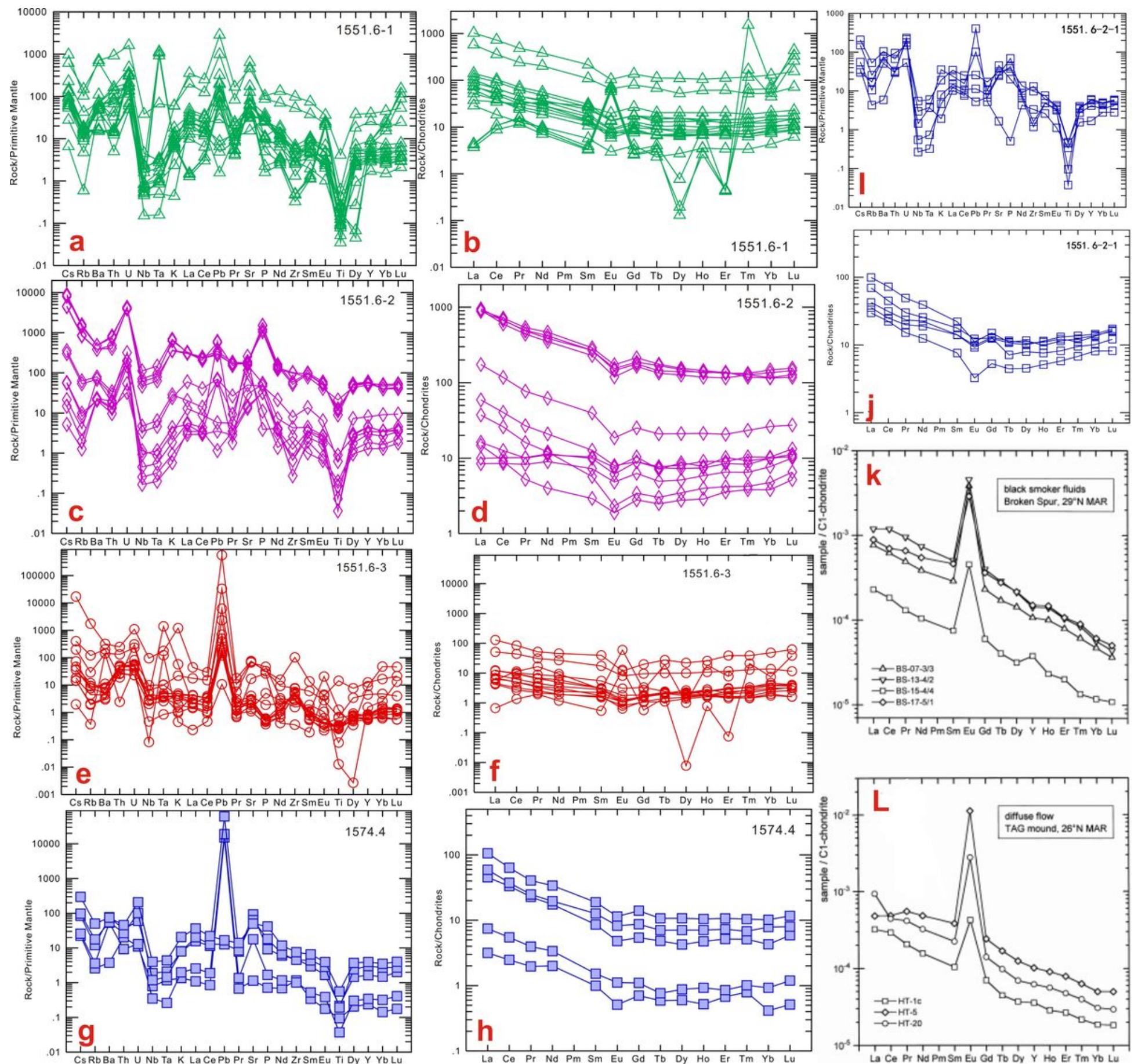

\section{Figure 6}

Standardized spider diagrams of REEs/chondrites and trace elements/primitive mantle from the hydrothermal chimney (Note: The data of panels $a$ and $b$ are from blue line No. 1 in Fig. 5, hydrothermal dolomite; the data of panels $c$ and d are from blue line No. 2 in Fig. 5, Mixture of hydrothermal sedimentary rock and mudstone; and the data of panels e and $f$ are from blue line No. 3 in Fig. 5 , hydrothermal pyrite. The data for panels $\mathrm{g}$ and $\mathrm{h}$ are from sample 1574.4, hydrothermal dolomite. The data for panels $i$ and $j$ are from sample 1551.6-2, hydrothermal dolomite). REYCN patterns of (k) hightemperature hydrothermal fluids from the Broken Spur vent site, $29^{\circ} \mathrm{N}$ Mid-Atlantic Ridge, and (L) lowtemperature diffuse hydrothermal flow at the TAG hydrothermal mound, $26^{\circ} \mathrm{N}$ Mid-Atlantic Ridge [37]. 


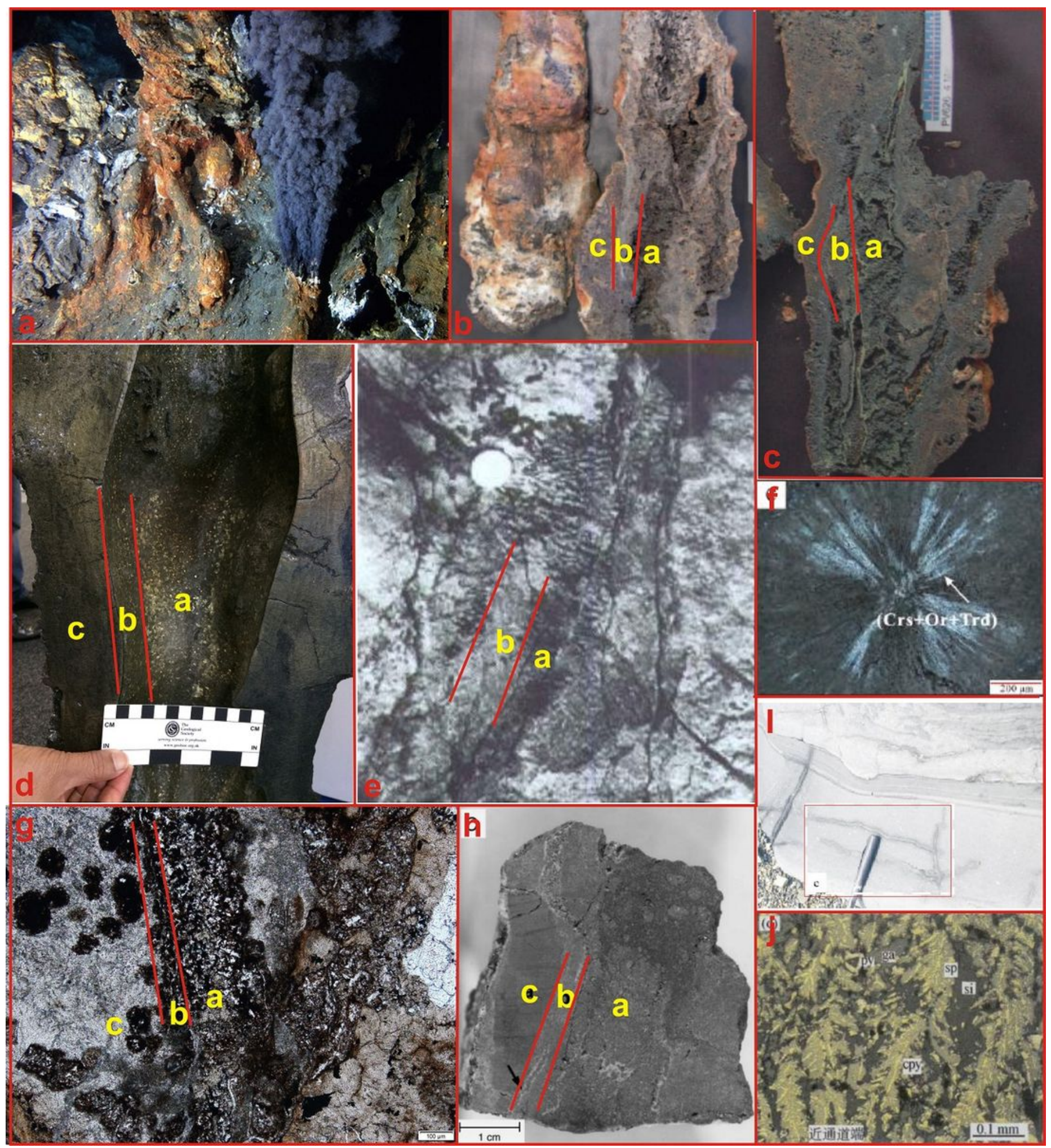

Figure 7

Comparison with previous research results a. Hydrothermal vent field near the Mid-Atlantic Ridge at $30^{\circ} \mathrm{N}[6]$. b. The outline of the black chimney of the Brothers submarine volcano [38]. c. Black chimney section of the Brothers submarine volcano[38]. d. The black chimney channel from the South African Geological Museum. Layer a in the figure is the outer wall of the channel, and layer b is the inner wall of the channel. Photograph by Li Hong in 2017. e. Photograph of hydrothermal sedimentary dolomite in a 
natural outcrop in the Sardinian mining area of Italy[31], similar to the shape of the hydrothermal chimney in Fig. 3b. f. The radial structure of the North Island hydrothermal zone, New Zealand[39] is similar to the radial structure of Fig. $3 \mathrm{~g}$. g. Channel of the hydrothermal chimney in this study; layer a in the figure is the outer wall of the channel, and layer $b$ is the inner wall of the channel. $h$. TAG hydrothermal mound, Mid-Atlantic Ridge, $26^{\circ} \mathrm{N}[40]$, similar to the channel structure of the study area in Fig. 3b. i. Drainage structure[41]. j. Black chimney in North China[23].
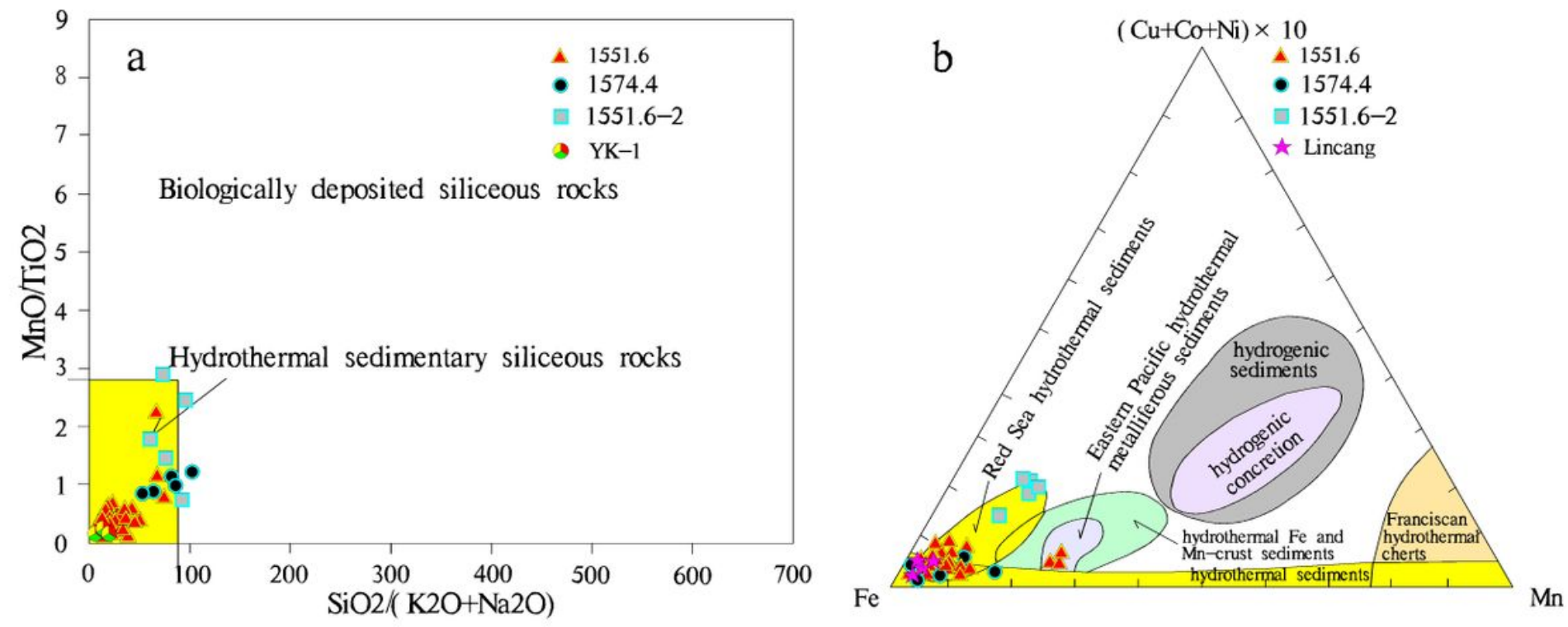

\section{Figure 8}

Discrimination diagrams for sedimentary rocks from the Zh22 well in the Ordos Basin (All samples are hydrothermal dolomite). a. SiO2/(K2O+Na2O)-MnO/TiO2 [26]. The data of 1551.6, 1574.4 and 1551.6-2 are from this study, and the data of YK-1 is from [9]. b. Fe-Mn-(Cu+Co+Ni)×10[25]. The data of 1551.6, 1574.4 and 1551.6-2 are from this study, and the data of YK-1 is from[9]. 


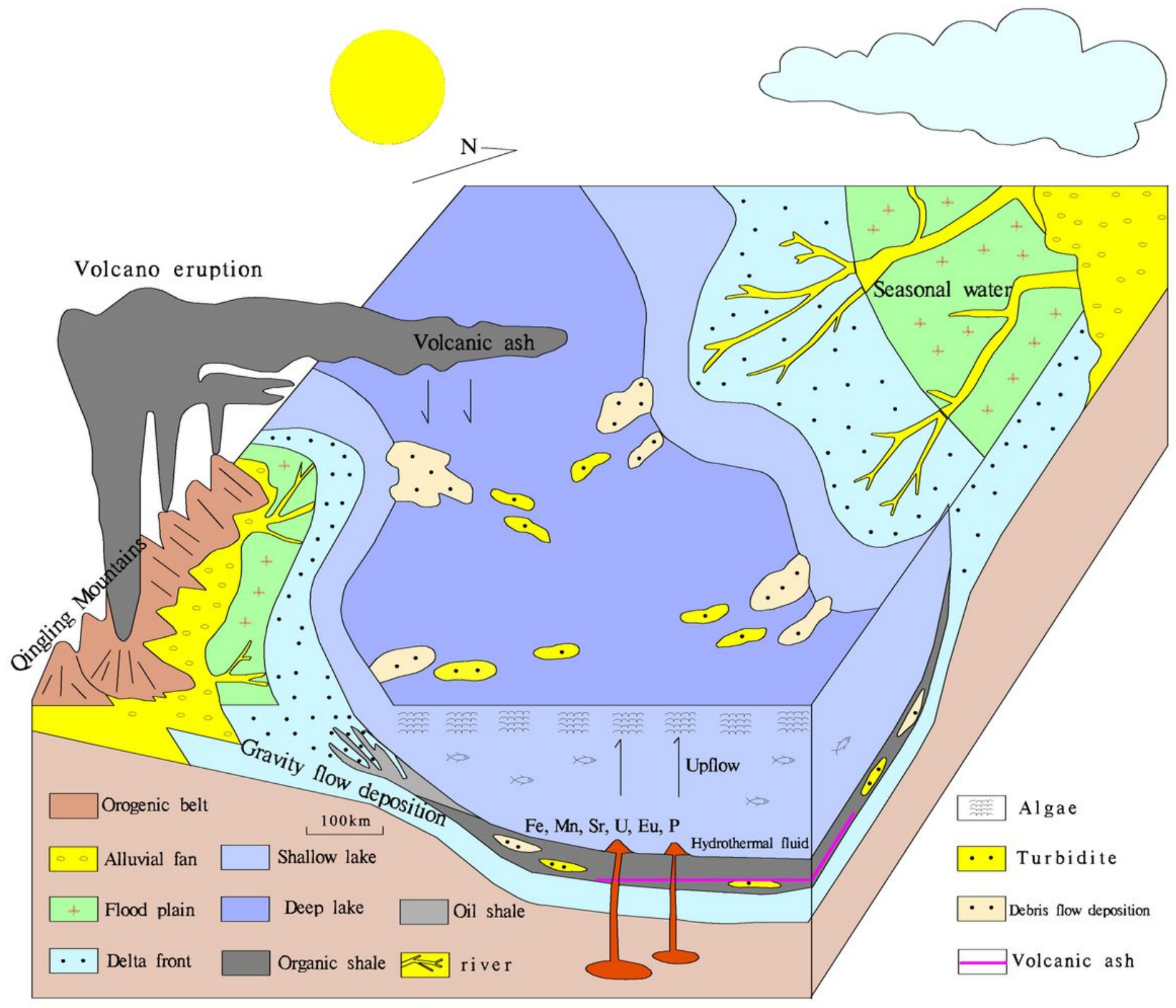

Figure 9

Sedimentary model map of the Late Triassic in the Ordos Basin

\section{Supplementary Files}

This is a list of supplementary files associated with this preprint. Click to download.

- 1 Mainelements.xls

- 2Geochemistryelements.xls

- 3Sisotope.xls 